\title{
Dapper Homolog 2
}

National Cancer Institute

\section{Source}

National Cancer Institute. Dapper Homolog 2. NCI Thesaurus. Code C105724.

Dapper homolog 2 (774 aa, $\sim 83 \mathrm{kDa}$ ) is encoded by the human DACT 2 gene. This protein is involved in the inhibition of signal transduction. 